\title{
The Influence of the Reflexive Position on the Regulation of the Students' Emotional Sphere
}

\author{
Natalya Matyash ${ }^{1,}{ }^{*}$ Tatyana Pavlova ${ }^{1}$, Svetlana Komarova ${ }^{1}$, Olga Golenkova ${ }^{1}$ \\ ${ }^{l}$ Bryansk State University named after academician I.G. Petrovsky, Bryansk, Russia \\ "Email: vds24@yandex.ru
}

\begin{abstract}
Modern psychological studies of the problem of reflection show its variety and importance. The emotional sphere of an individual also does not lose its significance for psychological research, mediating human behaviour. The article considers the conducted research of the influence of the reflexive position on the regulation of students' emotional states. It is revealed that various indicators of students' reflection (retrospective and prospective reflection of activity, reflection of communication, self-reflection and socioreflexion, differential type of reflection) are developed at an average level, manifestations of the emotional sphere (well-being, activity, mood. emotional experiences, self-control in the emotional sphere, activity and behaviour) of students are most favourable. The conducted one-factor analysis of the data obtained showed that the formed reflexive position affects the emotional sphere of students. The following characteristics of the reflexive position have the most significant influence on the emotional sphere: reflexivity, selfreflection, introspection and socioreflexion. The primary influence of the reflexive position is aimed at such features of the emotional sphere of students as mood, positive emotions and self-control of emotions.
\end{abstract}

Keywords: Reflection, Reflexive position, Emotions, Emotional states, Students.

\section{INTRODUCTION}

A large number of works by domestic and foreign authors are devoted to the scientific research of reflection, in which it is shown that the problem of reflection is multifaceted, represented by the presence of various aspects of its understanding. It is characteristic of Russian psychology that the analysis of the reflection phenomenon is associated with the characteristics of self-knowledge, regulation and self-development. The psychological mechanism of reflection is considered the ability of a person to turn consciousness on himself arbitrarily [1]. Reflection is defined as a principle that explains the organisation and development of the human psyche and its highest form - self-consciousness. The mechanisms of reflection perform the function of selfregulation and control, contribute to the harmonious development of personality [2-4]. Reflection makes it possible for a person to discover the meanings of his actions, to comprehend the problems of his character, worldview, attitude towards himself and other people, and also allows him to determine the perspective of others towards him [5]. S.L. Rubinstein pointed out that reflection takes a person beyond the limits of the life process, makes it possible to withdraw, to take a position outside of it. Reflection is considered an appeal to experience and planning, and designing a life path [4]. A.V. Karpov believes reflexivity to be a metaability controlled by the cognitive area of the psychic and acting as a regulator for the entire system [6]. N.F. Talyzina [7] defines reflection as "the ability of a person to be aware of what he is doing, and to argue, justify his activities."

Based on the analysis of modern psychological studies of reflection, we proposed the concept of a reflexive position. A reflexive position is a set of a person's reflexive qualities that determine the general orientation and main functions of a person's interpretation of a subjective reflection of reality. The reflexive position determines the place of reflection, interpretation and analysis of one's personality, behaviour, relationships in human life. 
The regulation of the emotional sphere of the individual, the ability to understand his emotional state and adequately build communication and activity on this basis is a significant psychological problem, both in theoretical and applied aspects. Studies of emotions and emotional states and associate them with the needs, desires and aspirations of a person, with his capabilities, with environmental conditions [8-12] Emotional states have a significant impact on actual human behaviour and are a reliable indicator of psychological well-being.

Emotional stability is essential for the successful learning process at the student age, fully manifested in mental balance. Students' emotional reactions are expressed in subjective experiences, their attitude to everything they learn and do, to the world around them [13]. Reflection makes it possible to avoid negative emotions and their consequences, errors of perception and understanding, the interpretation of actions and actions distorted by emotions, which positively contributes to the organisation of constructive psychological communication and interaction $[14,15]$.

Understanding the influence of reflection and the reflexive position of students on the regulation of the emotional sphere is of great practical importance for the organisation of the educational process at the university, for psychological and pedagogical support for the development of students' personalities.

\section{RESEARCH METHODS}

To identify the features of the influence of the reflexive position on the regulation of students' emotional states, we conducted an empirical study, during which the following methods were used:

1. Methodology for determining the level of reflexivity (A.V. Karpov, V.V. Ponomareva);

2. Methodology of the expression level and direction of reflection (M. Grant);

3. Questionnaire "Differential type of reflection" (D.A. Leontiev, E.M. Lapteva, E.N. Osin, A.Zh. Salikhova).
4. WBAM method: well-being, activity, mood (V.A. Doskin, N.A. Lavrentieva).

5. The method "Scale of differential emotions" (K. Izard, in the adaptation of A.B. Leonova).

6. Questionnaire to identify the severity of selfcontrol in the emotional sphere, activity and behaviour (G. S. Nikiforov, V. K. Vasiliev and S.V. Firsova).

Statistical data analysis methods included singlefactor analysis of variance (ANOVA), using the IBM SPSS Statistics 21.0 software.

The study involved undergraduate students of various study fields of the Bryansk State University named after Academician I.G. Petrovsky, Bryansk (Russia) (N=70).

\section{RESEARCH RESULTS}

The results of studying the features of the reflexive position of students using the method of determining the level of reflexivity (A.V. Karpov, V.V. Ponomareva, Table 1) show that students have average indicators for the types of reflection presented (retrospective reflection of activity, reflection of present activity, consideration of future activity, reflection of communication). Consequently, the analysis of activities already performed in the past and upcoming activities, planning, analysis of activities and behaviour in the current situation, and relationships with others for effective interpersonal interaction is sufficient.

Next, we will consider the results according to the method of M. Grant, which allows us to identify the features of self-reflection and socioreflexion. The average value for the first indicator is 37.2 points and for the second indicator 36.2. Students are able to analyse other people's ideas about them and their activities and build effective interaction based on socioreflexion.

Table 1. Average values according to the characteristics of students' reflection

\begin{tabular}{|l|c|}
\hline \multicolumn{1}{|c|}{ Types of reflection } & Indicators \\
\hline Retrospective reflection of activity & 27,7 \\
\hline Reflection on the present activity & 28,9 \\
\hline Consideration of future activities & 29,1 \\
\hline Reflection of communication & 30,2 \\
\hline General reflection & 115,65 \\
\hline
\end{tabular}


Table 2. The results of the study of students' emotional experiences

\begin{tabular}{|l|c|c|c|}
\hline Levels & Index of positive emotions & Index of negative emotions & $\begin{array}{c}\text { Index of anxiety-depressive } \\
\text { emotions }\end{array}$ \\
\hline High & 34 & 32 & 43 \\
\hline Average & 40 & 42 & 37 \\
\hline Low & 26 & 26 & 20 \\
\hline
\end{tabular}

Let's consider students' results using the method "Differential type of reflection" (D.A. Leontiev et al.). Systemic reflection, which allows you to look at yourself from the outside, has indicators of 29.4 points; indicators of introspection, concentration on your own experiences and states are 29.1 points. The average values on the "Quasi-Reflection" scale, reflecting reflections that are not directly related to the current life situation, are within the average range and amount to 28.5 points.

Next, we will analyse the data on the characteristics of the emotional sphere of students.

To study the emotional state of students in different areas of training, the WBAM method of V.A. Doskin, N.A. Lavrentieva was used.

A high level of well-being, energy, and cheerfulness was revealed in $32 \%$ of students, an average level in $40 \%$, and a low level in $28 \%$ of students. According to the "activity" scale, the following features were revealed: the high level is $46 \%$, the low level of activity was detected in $28 \%$ of students, and the average is $26 \%$. During the study of students' mood, it was revealed that $44 \%$ of students have a good mood, $36 \%$ have an average mood, and $20 \%$ have a low mood. If we analyse the severity of a particular condition in the whole group, we can say that students have the most marked activity and mood and a little less pronounced well-being.

The method "Scale of differential emotions" of K. Izard, adapted by A. Leonova, was used to study the nature of emotions. The results are presented in Table 2.
The data presented in the table show that students have a high and average level of both positive and negative and anxiety-depressive emotions.

In our study, the methodology of G. S. Nikiforov, V. K. Vasiliev and S. V. Firsova aimed at identifying the level of self-control in the emotional sphere, activity and behaviour was used (Table 3). It was revealed that $49 \%$ of students have an average level of self-control in the emotional sphere. $31 \%$ of the subjects have a high level, and $20 \%$ have a low level. Consequently, most students show stability in emotions and behaviour in various life situations.

\section{RESULTS DISCUSSION}

The comparative analysis of the data obtained by the students' levels and characteristics of reflection showed some features in the formation of this quality in the subjects. It was revealed that almost all aspects (retrospective and perspective reflection of activity, reflection of current activity, reflection of communication, self-reflection and socioreflexion, differential type of reflection) belong to the average indicators. Therefore, it can be noted that students' reflexive skills are developed at a sufficient level, a reflexive position concerning their personality, to other people, to activities, communication and interaction is formed.

The analysis of the characteristics of the emotional sphere of students based on the results of the conducted methods shows that all indicators are presented at medium and high levels (well-being, activity, mood.

Table 3. Manifestations of self-control in the emotional sphere, activity and behaviour

\begin{tabular}{|l|c|c|c|}
\hline \multicolumn{1}{|c|}{ Levels } & $\begin{array}{c}\text { Self-control in the } \\
\text { emotional sphere }\end{array}$ & $\begin{array}{c}\text { Self-control in the activity } \\
\text { Social self-control }\end{array}$ \\
\hline High & 31 & 43 & 29 \\
\hline Average & 49 & 34 & 40 \\
\hline Low & 20 & 23 & 31 \\
\hline
\end{tabular}


Table 4. Significant indicators of one-factor analysis of variance in terms of reflection and students' emotional sphere

\begin{tabular}{|c|c|c|c|c|c|}
\hline & & $\begin{array}{l}\text { Sum of } \\
\text { squares }\end{array}$ & $\begin{array}{l}\text { Average } \\
\text { Square }\end{array}$ & $\mathrm{F}$ & Value. \\
\hline \multirow{2}{*}{$\begin{array}{l}\text { Introspection and self- } \\
\text { control } \\
\text { emotions }\end{array}$} & Between groups & 122,577 & 61,288 & 3,682 & ,030 \\
\hline & Within groups & 1115,195 & 16,645 & 34 & 40 \\
\hline \multirow{2}{*}{$\begin{array}{l}\text { Socioreflexion and self- } \\
\text { control of emotions }\end{array}$} & Between groups & 87,897 & 43,949 & 2,561 & ,045 \\
\hline & Within groups & 1149,874 & 17,162 & & \\
\hline \multirow[t]{2}{*}{ Self-reflection and mood } & Between groups & 8,161 & 4,080 & 2,763 & ,050 \\
\hline & Within groups & 98,931 & 1,477 & & \\
\hline \multirow{2}{*}{$\begin{array}{l}\text { Reflexivity and positive } \\
\text { emotions }\end{array}$} & Between groups & 627,750 & 89,679 & 1,690 &, 012 \\
\hline & Within groups & 3290,035 & 53,065 & & \\
\hline
\end{tabular}

emotional experiences, self-control in the emotional sphere, activity and behaviour). This may indicate that students have positive emotions, favourable emotional states, psychological comfort.

For a more detailed analysis of the data, statistical processing of the results was used. One-factor analysis of variance (ANOVA) was applied using the IBM SPSS Statistics 21.0 software (Table 4).

Considering the data of one-factor analysis of variance, we can say that the statistically significant influence of reflection on the emotional sphere of the subjects was revealed by the following characteristics:

- introspection and self-control of emotions $(\mathrm{F}=3.682, \mathrm{p}>0.05$, at $\mathrm{r}=0.030)$. The expressed ability to deeply understand oneself, analyse one's actions affects the self-control of emotions in students of the entire sample. The ability to understand themselves, analyse their thoughts, feelings allow students to control their emotions in various life situations;

- socioreflexion and self-control of emotions $(\mathrm{F}=2.561, \mathrm{p}>0.05$, with $\mathrm{r}=0.045)$. The ability to understand the feelings, motives of behaviour, actions of other people allow the subjects to control their own emotions;

- self-reflection and $\operatorname{mood}(\mathrm{F}=2.763, \mathrm{p}>0.05$, at $\mathrm{r}=$ $0.050)$. The intensity of self-reflection affects the subjects' mood, helps them realise their emotional states, and regulates them. The constant analysis and control of their actions by students affects their mood;

- reflexivity and positive emotions $(\mathrm{F}=2.69, \mathrm{p}>0.05$, at $\mathrm{r}=0.012$ ). The ability of the test students to analyse their activities, behaviour in specific life situations cause them a positive emotional response. The revealed connection indicates that focusing on their state and experiences allow the subjects to have positive emotions.

\section{CONCLUSIONS}

The conducted research, based on the analysis and interpretation of data, allowed us to identify the features of the reflexive position and reflection of upcoming activities and communication, self-reflection and socioreflexion, various types of reflection, showed that the reflexive position of students is formed at a sufficient level, work on understanding their personality, activities and behaviour bring significant results, students are aware of themselves as subjects of their own life and actively act in a social environment.

The study of the reflexive position, covering indicators of the general level of reflexivity, a retrospective reflection of activity, a reflection of upcoming activities and communication, self-reflection and socioreflexion, various types of reflection, showed that the reflexive position of students is formed at a sufficient level, work on understanding their personality, activity and behaviour bring significant results, students are aware of themselves as subjects of their own life and actively act in a social environment.

The study of the emotional sphere of students, including the diagnosis of emotional states, well-being, activity, mood, differential emotions, identification of the level of self-control in the emotional sphere, activity and behaviour, showed the presence of positive emotions in students, favourable emotional states that contribute to efficiency and effective activity.

The conducted one-factor analysis of variance of the data obtained showed that the formed reflexive position affects the indicators of the emotional sphere of students. 
Such characteristics found the most significant influence on the emotional sphere: reflexivity, selfreflection, introspection, and socioreflexion. The most significant influence from the reflexive position is such features of students' emotional sphere as mood, positive emotions, and self-control of emotions.

The obtained results show that the development of the reflexive position of students contributes to the regulation of the emotional sphere of students. In this regard, there are opportunities for students' psychological support to develop reflexive skills and emotional self-regulation. Such a direction of psychological work may include educational training, group discussions, and individual and group tasks within the framework of the studied disciplines.

\section{REFERENCES}

[1] D.A. Leontiev, A.Zh. Averina, The phenomenon of reflection in the context of self-regulation [Fenomen refleksii $\mathrm{v}$ kontekste problemy samoregulyacii], Psychological research: electronic scientific journal [sihologicheskie issledovaniya: elektronnyj nauchnyj zhurnal], Vol. 2(16), 2011. Retrieved from: http://psystudy.ru/index.php/num/2011n2-16/463leontiev-averina16.html

[2] B.G. Ananyev, Personality, subject of activity, individuality [Lichnost', sub"ekt deyatel'nosti, individual'nost'], Direct Media [Direkt-Media], 2008, 134 p.

[3] L.S. Vygotsky, History of the development of higher mental functions [Istoriya razvitiya vysshih psihicheskih funkcij], Pedagogy [Pedagogika], 1983, $228 \mathrm{p}$.

[4] S.L. Rubinstein, Fundamentals of General Psychology [Osnovy obshchej psihologii], Piter, 2013, 713 p.

[5] Ya.A. Ponomarev, Psychology of creativity: general, differential, applied [Psihologiya tvorchestva: obshchaya, differencial'naya, prikladnaya], Science [Nauka], 1990, 224 p.

[6] A.V. Karpov, Psychology of Reflexive mechanisms of Activity [Psihologiya refleksivnyh mekhanizmov deyatel'nosti], Institute of Psychology of the Russian Academy of Sciences [Institut psihologii RAN], 2014, 424 p.

[7] N.F. Talyzina, Pedagogical Psychology [Pedagogicheskaya psihologiya], Academy [Akademiya], 1998, $288 \mathrm{p}$.

[8] A.N. Leontiev, Activity. Conscience. Personality, Meaning [Deyatel'nost'. Soznanie, Lichnost', Smysl], Academy [Akademiya], 2005, 352 p.
[9] K.T. Strongman, The Psychology of Emotion, Wiley, $277 \mathrm{p}$.

[10] K.E. Izard, Psychology of Emotions [Psihologiya emocij], Piter, 2007, 464 p.

[11] B. Parkinson, P. Totterdell, R.B. Briner, S. Reynolds, Changing Moods: The Psychology of Mood and Mood Regulation, Longman, 1996, 254 p.

[12] L.F. Barrett, How Emotions are born: A Revolution in Understanding the Brain and Emotion Management [Kak rozhdayutsya emocii: Revolyuciya $\mathrm{v}$ ponimanii mozga i upravleniya emociyami], Mann, Ivanov and Ferber, 2018, 432 p.

[13] V.A. Mazilov, I.N. Slepko, Psychological characteristics and development of initial teacher education students' reflective abilities at nondegree-granting and degree-granting institutions: a comparative analysis, Science for Education Today 4 (2020) 91-108. Retrieved from: http://dx.doi.org/10.15293/2658-6762.2004.06

[14] A.O. Prokhorov, A.V. Chernov, The influence of reflection on students' mental states in the process of educational activity [Vliyanie refleksii na psihicheskie sostoyaniya studentov $\mathrm{v}$ processe uchebnoj deyatel'nosti], Experimental Psychology [Eksperimental'naya psihologiya] 7(2), (2014) 8293.

[15] R.G. Gabdrakhmanova, R.M. Khusainova, S.E. Chirkina, Reflexive activity of a student in the process of professional training, Actual problems of formation of the culture of intellectual work of future specialists: trends, paradigms, experience [Refleksivnaya deyatel'nost' studenta $\mathrm{v}$ processe professional'noj podgotovki, Aktual'nye problemy formirovaniya kul'tury intellektual'nogo truda budushchih specialistov: tendencii, paradigmy, opyt], PNPI, Pavlodar [PNPI, Pavlodar], 2015, pp. 234-242. 